\title{
Clinical cases of measles in pregnant women
}

\author{
O. V. Riabokon ${ }^{\star A, E, F}$, N. H. Izbytska ${ }^{\mathrm{B}, \mathrm{C}}$, S. O. Bilokobyla ${ }^{\mathrm{B}, \mathrm{C}, \mathrm{D}}$, T. Ye. Onishchenko ${ }^{\mathrm{B}, \mathrm{C}}$, \\ Yu. Yu. Riabokon ${ }^{\mathrm{C}, \mathrm{E}}$
}

Zaporizhzhia State Medical University, Ukraine

A - research concept and design; B - collection and/or assembly of data; C - data analysis and interpretation; D - writing the article; $\mathrm{E}$ - critical revision of the article; $\mathrm{F}$ - final approval of the article

The aim of the work is to analyze the clinical course of measles in hospitalized pregnant women for the period of 2017-2019 years.

Materials and methods. The clinical course of measles was analyzed in 4 pregnant patients with this disease aged from 19 to 30 years, who were hospitalized in the Regional Infectious Clinical Hospital during 2017-2019 years. The diagnosis of measles was established according to the WHO criteria (2013). All pregnant women with measles had epidemiological history of contact with measles patients and in all cases diagnosis of measles was confirmed by detection measles IgM in the Zaporizhzhia Regional Laboratory Center of the Ministry of Health of Ukraine.

Results. It was found that in all pregnant women who were included in the study, measles developed in the third trimester of pregnancy, one patient was pregnant with twins. The development of measles was accompanied by the appearance of typical clinical symptoms with formation of moderate $(n=2)$ and severe $(n=2)$ course. One pregnant woman had never been vaccinated against measles during her lifetime; other three patients had no documented evidence of previous measles vaccination.

Most of the pregnant women ( 3 out of 4 ) had complications of measles from respiratory system: acute bronchitis $(n=1)$, acute bronchitis with pulmonary edema and respiratory failure of I-II degree $(n=1)$, community-acquired lower lobe right-sided pneumonia, left lung atelectasis, respiratory failure of III degree $(n=1)$.

Only in one 26-year-old pregnant measles had moderate course without complications. In two pregnant women development of complications needed treatment in the intensive care unit. In 30-year-old pregnant woman with twins with gestational age of 27-28 weeks from the first day of the rash, complications like measles enteritis appeared, and from the second day of the rash there were signs of acute respiratory failure due to development of pulmonary edema. On the background of complex medical treatment with use of oxygen therapy, patient recovered, pregnancy progressed without complications.

However, in one unvaccinated 25-year-old woman, who had not been vaccinated with measles, severe course of the disease was accompanied not only by the development of complications, but also had adverse effects on pregnancy. In this patient, measles was complicated by community-acquired right-sided pneumonia of group IV, left lung atelectasis, acute respiratory failure degree III, toxic-hypoxic encephalopathy and brain edema, which required mechanical ventilation. In addition, chronic hepatitis $\mathrm{C}$ was first diagnosed. Against this background, there was premature birth within 30 weeks.

Conclusions. According to analysis of four observations we can determine that measles in pregnancy has both moderate and severe course, but development of complications from respiratory system was recorded in the majority of patients (3 out of 4 patients). In severe cases of measles in pregnant women treatment in the intensive care unit was required due to development of pulmonary edema on the background of acute bronchitis in combination with measles enteritis $(n=1)$, community-acquired right-sided pneumonia in combination with left lung atelectasis $(n=1)$. The above clinical observation demonstrates the development of a very severe complicated course of measles in previously unvaccinated 25 -year-old pregnant, which led to premature birth in the gestation period of 30 weeks.

\section{Киінічні випадки кору у вагітних}

\section{О. В. Рябоконь, Н. Г. Ізбицька, С. О. Білокобила, Т. Є. Оніщенко, Ю. Ю. Рябоконь}

Мета роботи - проаналізувати клінічний перебіг кору у госпіталізованих вагітних за період 2017-2019 рр.

Матеріали та методи. Проаналізували клінічний перебіг кору у 4 вагітних віком від 19 до 30 років. Пацієнтки госпіталізовані в Обласну інфекційну клінічну лікарню протягом 2017-2019рр. Діагноз кору встановили за критеріями ВОО3 (2013). Усі вагітні, які хворі на кір, мали дані епідеміологічного анамнезу щодо контакту з хворими на кір; у всіх випадках діагноз кору був підтверджений виявленням IgM до вірусу кору в «Запорізькому обласному лабораторному центрі МОЗ України».

Результати. Встановили, що в усіх вагітних, які були залучені в дослідження, кір розвинувся в третьому триместрі вагітності, одна пацієнтка була вагітна двійнею. Розвиток кору супроводжувався появою типової клінічної симптоматики кору з формуванням середньотяжкого $(n=2)$ і тяжкого $(n=2)$ перебігу. Одна вагітна протягом життя жодного разу не була щеплена проти кору, інші 3 пацієнтки не мали документального підтвердження попередньої вакцинації проти кору.

У більшості вагітних (3 із 4) виявили ускладнення кору з боку респіраторної системи: гострий бронхіт ( $\mathrm{n}=1)$, гострий бронхіт із набряком легень і дихальною недостатністю I-ІІ ступеня $(\mathrm{n}=1)$, позагоспітальна правобічна нижньодольова пневмонія, ателектаз лівої легені, дихальна недостатність III ступеня $(\mathrm{n}=1)$. Тільки в однієї вагітної віком 26 років кір
Key words: measles in pregnant women, clinic, complications.

Pathologia 2020; 17 (2), 269-274

*E-mail: ryabokonzsmu@ukr.net 
мав середньотяжкий перебіг без ускладнень. Двоє вагітних унаслідок розвитку ускладнень потребували лікування в реанімаційному відділенні. У вагітної двійнею віком 30 років із терміном гестації 27-28 тижнів із першого дня висипки з'явилися ознаки такого ускладнення, як ентерит, а з другого дня висипки - ознаки гострої дихальної недостатності внаслідок розвитку набряку легень. На тлі комплексного медикаментозного лікування із застосуванням оксигенотерапії пацієнтка одужала, вагітність перебігала без ускладнень. Але в однієї нещепленої раніше проти кору пацієнтки віком 25 років тяжкий перебіг кору не лише супроводжувався розвитком ускладнень, але й мав несприятливі наслідки на перебіг вагітності. У цієї пацієнтки кір ускладнився позагоспітальною правосторонньою пневмонією IV групи, ателектазом лівої легені, гострою дихальною недостатністю III ступеня, токсико-гіпоксичною енцесралопатією, набряком головного мозку, що потребувало проведення штучної вентиляції легень. До того ж у неї вперше діагностували хронічний гепатит С. На цьому тлі відбулися передчасні пологи в термін 30 тижнів.

Висновки. За даними аналізу 4 спостережень можна стверджувати: кір у вагітних має і середньотяжкий, i тяжкий перебіг, але розвиток ускладнень з боку респіраторної системи зареєстрували в більшості хворих (3 із 4). При тяжкому перебігу кору вагітні потребували лікування в реанімаційному відділенні внаслідок розвитку набряку легень на тлі гострого бронхіту в комбінації з коровим ентеритом $(n=1)$, позагоспітальної пневмонії справа в поєднанні з ателектазом лівої легені ( $n=1)$. Наведене клінічне спостереження демонструє розвиток украй тяжкого ускладненого перебігу кору в нещепленої раніше вагітної віком 25 років, що призвело до передчасних пологів у термін гестації 30 тижнів.

Киючевые слова: корь у беременных, клиника, осложнения.

Патология. 2020.

T. 17, № 2(49).

C. 269-274

\section{Клинические случаи кори у беременных}

\section{Е. В. Рябоконь, Н. Г. Избицкая, С. А. Белокобыла, Т. Е. Онищенко, Ю. Ю. Рябоконь}

Цель работы - проанализировать клиническое течение кори у госпитализированных беременных за период 20172019 гг.

Материалы и методы. Проанализировали клиническое течение кори у 4 беременных в возрасте от 19 до 30 лет. Женщины госпитализированы в Областную инфекционную клиническую больницу в течение 2017-2019 гг. Диагноз кори устанавливали согласно критериям ВО3 (2013). Все беременные, больные корью, имели данные эпидемиологического анамнеза контакта с больными корью. Во всех случаях диагноз кори подтвержден обнаружением IgM к вирусу кори в «Запорожском областном лабораторном центре Министерства здравоохранения Украины».

Результаты. Установлено, что у всех беременных, которые включены в исследование, корь развилась в III триместре беременности, одна пациентка была беременна двойней. Развитие кори сопровождалось появлением типичной клинической симптоматики с формированием среднетяжелого $(\mathrm{n}=2)$ и тяжелого $(\mathrm{n}=2)$ течения. Одна беременная за всю жизнь ни разу не была привита против кори, остальные 3 пациентки не имели документального подтверждения ранее проведенной вакцинации против кори.

У большинства беременных (3 из 4) отмечены осложнения кори со стороны дыхательной системы: острый бронхит $(n=1)$, острый бронхит с отеком легких и дыхательной недостаточностью I-II степени $(n=1)$, внегоспитальная правосторонняя нижнедолевая пневмония, ателектаз левого легкого, дыхательная недостаточность III степени $(\mathrm{n}=1)$. Только у одной беременной в возрасте 26 лет корь имела среднетяжелое течение без осложнений. Двое беременных вследствие развития осложнений нуждались в лечении в реанимационном отделении. У беременной двойней в возрасте 30 лет со сроком гестации 27-28 недель с первого дня сыпи появились признаки такого осложнения, как энтерит, а со второго дня сыпи - признаки острой дыхательной недостаточности в результате развития отека легких. На фоне комплексного медикаментозного лечения с применением оксигенотерапии пациентка выздоровела, беременность протекала без осложнений. У одной непривитой ранее против кори пациентки в возрасте 25 лет тяжелое течение кори не только сопровождалось развитием осложнений, но и имело неблагоприятные последствия на течение беременности. У этой пациентки корь осложнилась внегоспитальной правосторонней пневмонией IV группы, ателектазом левого легкого, острой дыхательной недостаточностью III степени, токсико-гипоксической энцефалопатией, отеком головного мозга, что требовало проведения искусственной вентиляции легких. К тому же у нее впервые диагностирован хронический гепатит С. На этом фоне произошли преждевременные роды в сроке 30 недель.

Выводы. По данным четырех наблюдений можно отметить, что корь у беременных имеет и среднетяжелое, и тяжелое течение, однако развитие осложнений со стороны дыхательной системы зарегистрировано у большинства больных (3 из 4). При тяжелом течении кори беременные нуждались в лечении в реанимационном отделении вследствие развития отека легких на фоне острого бронхита в сочетании с коревым энтеритом $(n=1)$, внегоспитальной пневмонии справа в сочетании с ателектазом левого легкого $(n=1)$. Приведенное клиническое наблюдение демонстрирует развитие крайне тяжелого осложненного течения кори у непривитой ранее беременной в возрасте 25 лет, что привело к преждевременным родам в сроке гестации 30 недель.

Measles is one of the most contagious potentially fatal infectious diseases that can be completely prevented by timely vaccination. According to $\mathrm{WHO}$, in 2017 year a significant increase in the incidence of measles in Europe was seen. In particular, in the first six months of 2019 year, almost 90000 cases of measles were detected, which is higher than in whole of 2018 year, in which 84000 cases of this infection were recorded. Ukraine is in the top ten countries with the highest number of measles cases in 2018 year [1]. However, these years have seen a rise in measles rates in many countries, including the United States, Africa. The critical situation with measles has developed in the Philippines, in this country rate of population vaccination in different areas varies only within 30-60\% [1]. The current epidemic situation is characterized by a change in circulating viruses 
genotypes with predominance of genotypes B3, D8, D9, in contrast to predominance of the D6 genotype fifteen years ago [2,3] and indicates a loss of control of infection due to disadvantages of immunoprophylaxis [1].

A significant feature of the current epidemic situation is prevalence of adult measles in the European region [4-6]. According to serological studies in Ukraine, the most vulnerable age group of adults were persons aged $16-30$ years, of whom only $78.1 \%$ had immunity against measles, which coincides with the high specific gravity of this age category among measles patients [7]. A population-based study of anti-measles immunity in pregnant women in Zaporizhzhya region showed that in the last 10 years only $60 \%$ of pregnant women had antibodies against measles virus [8]. It is believed that the loss of post-vaccine anti-measles antibodies occurs in most adults for ten years after vaccination, which in modern epidemic conditions necessitates consideration of additional vaccination against measles exactly by adults [9]. An increase in the incidence of measles among adults leads to a higher incidence of the disease in pregnant women. Publications in recent years demonstrate risk of severe measles complications in pregnant women, which can lead to preterm birth or even stillbirth [10-12]. The above proves need to study the course of measles in pregnant women.

\section{Aim}

To analyze the clinical course of measles in hospitalized pregnant women for the period of 2017-2019 years.

\section{Materials and methods}

The study included 4 pregnant patients with measles, aged between 19 and 30 years old, who were hospitalized to inpatient unit of municipal institution "Regional Infectious Clinical Hospital" of Zaporizhzhia Regional Council during 2017-2019 years. The diagnosis of measles was established according to WHO criteria (2013) [13]. All pregnant with measles in epidemiological history had contact with measles patients and in all cases diagnosis was confirmed by the detection of measles virus in serological laboratory of the State Institution "Zaporizhzhia Regional Laboratory Center of the Ministry of Health of Ukraine". All patients underwent traditional clinical laboratory studies, X-ray examination, blood testing for antibodies to human immunodeficiency virus and markers of viral hepatitis, all pregnant patients with measles were consulted by an obstetrician-gynecologist.

\section{Results}

The results of the analysis showed that in all pregnant women who were included in the study, measles developed in the third trimester of pregnancy with a gestation period ranging from 27 to 32 weeks, one patient was pregnant with twins. The development of measles was accompanied by appearance of typical symptoms with the presence of a prodromal period from 1 to 5 days with catarrhal manifestations, appearance of scleroconjunctivitis, characteristic pathognomonic enanthema in the form of Filatov-Koplik spots, a rash period with stages of profuse exanthema appearance of maculopapular nature, which had a confluent character and was accompanied by febrile fever. The course of the disease had both moderate $(n=2)$ and severe $(n=2)$ course. It should be noted that one pregnant woman was never vaccinated against measles during her lifetime, the other three patients could not provide any documentary evidence of measles vaccination previously performed.

Most of the pregnant women ( 3 out of 4 ) had complications of measles from the respiratory system: acute bronchitis $(n=1)$, acute bronchitis with pulmonary edema and respiratory failure of $I-I I$ degree $(n=1)$, community-acquired lower lobe right-sided pneumonia, left lung atelectasis, respiratory failure of III degree $(n=1)$. Only in one pregnant woman L., 26 years old (inpatient card number 7820), measles had moderate course without complications with development of leukopenia $3.7 \times 10^{9} /$.

In one patient, 19 years old (inpatient card number 1055), moderate course of measles was complicated by acute bronchitis, which was accompanied by a leukemoid reaction with pronounced shift of leukocyte formula to the left with appearance of myelocytes $-1 \%$, metamyelocytes $-1 \%$, increase in stab forms up to $18 \%$, moderate thrombocytopenia - $146 \times 10 \%$.

Two pregnant women with development of complications needed treatment in the intensive care unit. In pregnant $C$. with twins, 30 years old, with gestation period of 27-28 weeks (inpatient card number 2809). from the first day of the rash there was diarrhea up to 4 times a day, which testified development of complication such as enteritis, and from the second day of the rash, maculopapular exanthema was very abundant, shortness of breath appeared up to 42 in 1 minute at rest, auscultatory there was hard breathing with weakening in the lower lobes, decreasing of $\mathrm{SaO}_{2}$ saturation up to $93 \%$, pulmonary pattern intensification was revealed radiographically, vascular deformity, shallow drain shadows, the plethora of lung roots, which indicating development of pulmonary edema. In the hemogram of this patient development of leukemoid reaction was also noted with leukocytosis - $11.7 \times 10^{9} /$, neutrophilosis $97 \%$ with toxic granularity of neutrophils, shift of leukoformula to the left with appearance of myelocytes $1 \%$, metamyelocytes $-1 \%$, increase in stab forms up to $20 \%$, with development of severe lymphopenia $-2 \%$. In addition, a mononuclear reaction with a transient onset of $1 \%$ of atypical mononuclear cells was recorded within three days. Oxygen therapy, combination of antibacterial therapy with intravenous cefepime and azithromycin, intravenous bioven and L-arginine were performed, followed by positive dynamics. The patient was discharged with recovery, pregnancy progressed without complications.

However, in one patient, severe course of measles was accompanied not only by the development of complications, but also adverse effects on the course of pregnancy. Thus, patient K., 25 years old (inpatient card number 7554), was admitted to infectious department on $12 / 21 / 2018$ with complaints of fever up to $39.2{ }^{\circ} \mathrm{C}$, 
cough, shortness of breath, chest discomfort, pain in the eyeballs, skin rash.

From anamnesis of the disease it was known that she became ill on $12 / 16 / 2018$ with fever within $39.0-39.5^{\circ} \mathrm{C}$, dry cough, pain in the eyeballs. These symptoms persisted for four days, due to which on 12/19/2018 patient sought medical attention and was hospitalized with diagnosis of "acute respiratory viral infection" at the Regional Perinatal Center, since patient was pregnant with a gestation period of 30 weeks. Radiologically, it was diagnosed community-acquired lower lobe right-sided pneumonia, which was regarded as a complication of influenza. Antiviral treatment with oseltamivir $150 \mathrm{mg} 2$ times a day, oxygen therapy in the mask mode were prescribed, antibacterial therapy was carried out intravenously with azithromycin, meropenem, symptomatic therapy. In the evening of $12 / 20 / 2018$, large maculopapular rash appeared on the face skin, patient's condition worsened significantly due to increase signs of endotoxicosis, appearance of toxic encephalopathy, respiratory failure of II degree, which was characterized by rapid increase of breathlessness to 40 per 1 minute, decrease of $\mathrm{SaO}_{2}$ from 98 to $93 \%$, despite constant masked oxygen therapy. Given the appearance of characteristic rash, the presence of positive symptom of Filatov-Koplik in pregnant woman "Measles, period of rash, severe course, complicated by community-acquired lower lobe right-sided pneumonia with respiratory failure II degree" was diagnosed.

The patient was immediately transferred to the intensive care unit of the Regional Infectious Clinical Hospital at night of $12 / 21 / 2018$. On examination, condition of pregnant patient was extremely severe: body temperature $-38.5^{\circ} \mathrm{C}$, expressed phenomena of toxic-hypoxic encephalopathy (episodes of inhibition were replaced by aggressive behavior), profuse maculopapular lesions on the skin of face, breast, shoulders, swelling of the face, severe scleroconjunctivitis, held hemodynamics independently (blood pressure $-110 / 70 \mathrm{mmHg}$, heart rate 115 per minute). The condition of the patient rapidly deteriorated due to progression of respiratory failure signs: respiratory rate increased up to 48 per minute, $\mathrm{SaO}_{2}$ decreased to $90 \%$, cyanosis of the lips appeared, auscultatory breathing was weakening in the lower sections on both sides. Given the increase in respiratory failure to grade II-III, patient was transferred to mechanical ventilation (MV), against which $\mathrm{SaO}_{2}$ increased up to $99 \%$. History data were clarified by relatives: contact with measles patient about two weeks ago, pregnant with measles was not vaccinated at all. As a result of laboratory data at hospitalization: anemia ( $\mathrm{Er}-$ $\left.3.89 \times 10^{12} / \mathrm{l}, \mathrm{Hb}-105 \mathrm{~g} / \mathrm{l}\right)$, leukocytosis - $10.8 \times 10^{9} / \mathrm{l}$, neutrophilosis - $89 \%$, stab shift - $18 \%$, lymphopenia $8 \%$, ESR acceleration - $57 \mathrm{~mm} / \mathrm{h}$, platelets - within the norm $363 \times 10^{9} /$; liver tests indicators in analysis were within reference values, despite the first diagnosed hepatitis C "anti-HCV+", diagnosis of influenza was excluded laboratory in blood test by polymerase chain reaction, the study on anti-HIV gave a negative result.

In the intensive care unit on $12 / 21 / 2018$, X-ray examination was repeated: in the projection of the lower lobe of right lung infiltration of lung tissue was present. The use of oseltamivir was stopped, antibacterial therapy was prolonged, lasolvan, intravenous biovenes, glucocorticosteroids in dose $2 \mathrm{mg} / \mathrm{kg}$ were administered.

On 12/22/2018 $\mathrm{SaO}_{2}$ was suddenly reduced to $93 \%$, auscultatory left breathing was practically absent, in connection with that $\mathrm{X}$-ray examination was carried out: total left lung atelectasis, right-side lower lobe pneumonia, Th5 level of intubation tube. Bronchoscopy was performed for the purpose of sanitation. When conducting bronchoscopy, mucous membrane of trachea is hyperemic with fibrinous coating in the lower part of trachea, mucous membrane of the right and left bronchi is hyperemic, edematous, injected with fibrinous coating, mucous membrane of the lobar and segmental bronchi is diffusely edematous, mucopurulent secretion without blood impurities was determined, sanitized with saline carried out, in conclusion: bilateral endobronchitis of I-II degree. After rehab bronchoscopy, respiration in the left lung was restored, $\mathrm{SaO}_{2}$ increased up to $98 \%$. The pregnant patient was examined by an obstetrician-gynecologist, fetal heartbeat - rhythmic, 136-142 per 1 min, with a cardiotocographic monitoring Fischer score of 8 points.

$12 / 23 / 2018$ at 14.00 genital mucous-bloody discharge appeared. When examined by an obstetriciangynecologist: uterus comes into tone, fetal position is longitudinal, heartbeat of the fetus is 150 per 1 minute, light amniotic fluid is flowing, opening of the cervix is 5 $\mathrm{cm}$, there is no fetal bladder, head is present. The decision was made to give birth conservatively, actively to give birth in the third period with using of oxytocin. At 19.45, a live premature baby girl weighing $1560 \mathrm{~g}$ was born, with Apgar score of $4-5$ points. When examined by a neonatologist, condition of the child is severe due to cardio-respiratory and neurological disorders, during auscultation crepitation was found in the lungs, prematurity of 30 weeks, the child is transferred to MV.

After childbirth correction of antibacterial therapy was performed: metronidazole was administered intravenously at $500 \mathrm{mg} 3$ times a day, vancomycin $1.0 \mathrm{~g} 2$ times a day, continued with meropenem. During laboratory control on 12/24/2018 intensification of anemia $(\mathrm{Er}-3.1$ $\left.\times 10^{12} / \mathrm{l}, \mathrm{Hb}-97 \mathrm{~g} / \mathrm{l}\right)$, reduction of leukocytosis $-9.4 \times$ $10 \% /$, recovery of leukopoietic indices were determined: stab neutrophils - $4 \%$, lymphocytes - $29 \%$, remaining accelerated ESR - $57 \mathrm{~mm} / \mathrm{h}$; indicators of liver and functional kidney tests were within reference values.

Before 12/27/2018 patient was on the $\mathrm{MV}, \mathrm{SaO}_{2}$ was $96 \%$, radiologically with repeated control there was occurrence of certain positive dynamics: left lung normal size without pathology, right-side in projection of the lower lobe infiltration of lung tissue was determined, intubation tube at the Th3 level. However, in hemogram from $12 / 27 / 2018$ transient increase of anemia $\left(\mathrm{Er}-2.8 \times 10^{12} / /\right.$, $\mathrm{Hb}-82 \mathrm{~g} / \mathrm{l})$, development of leukemoid reaction with increase of leukocytosis up to $11.7 \times 10^{9} / /$, appearance of myelocytes $-1 \%$, metamyelocytes $-1 \%$, increased stab neutrophils up to $8 \%$, the appearance of toxic granularity of neutrophils were determined. In addition, there was occurrence of atypical mononuclear cells within two days in the amount of 1-2\%. The liver and functional kidney tests remained within normal range.

On 12/27/2018 MV was stopped. The patient's condition was severe, respiratory rate 22 per 1 minute, 
$\mathrm{SaO}_{2}$ within 94-95\% with masked oxygen therapy, hemodynamics stable (blood pressure $110 / 70 \mathrm{mmHg}$, heart rate 68 per $1 \mathrm{~min}$ ), patient was in the mind, executing commands, Glasgow score 12 points, auscultatory breathing was hard on both sides.

From $12 / 28 / 2018$ to $12 / 31 / 2018$, the patient's condition is stably severe, respiratory rate -16 per 1 minute, $\mathrm{SaO}_{2}$ - within 95-96\% with masked oxygen therapy, without oxygen therapy - $94 \%$. Auscultation in the lower lungs indicates scattered wheezing. Hemodynamics are stable. The X-ray examination on $12 / 28 / 2018$ showed the infiltration of lung tissue persisting in the projection of right lower lobe. The diagnosis of measles was confirmed by the release of IgM to measles virus (№ 203 dated 12/28/2018).

Final diagnosis: "Measles (IgM to measles virus positive), typical form, severe course. Communityacquired right-sided pneumonia, group IV. Left lung atelectasis. Acute respiratory failure III degree. Toxichypoxic encephalopathy. Brain edema. Pregnancy I, 30 weeks, childbirth I. Chronic hepatitis C (anti-HCV +) is first established". The patient was transferred to the pulmonology department of the Regional Clinical Hospital for further treatment on 12/31/2018.

Thus, the above clinical observation demonstrates the development of very severe complicated course of measles in previously unvaccinated 25-year-old pregnant, which led to premature birth at the gestation period of 30 weeks.

\section{Discussion}

Many authors, considering and analyzing the complications of measles, highlight a special subgroup of adults pregnant women. In pregnancy there is a potentiation of two conditions that lead to immunosuppression, in which on the one hand there is measles anergy, on the other physiological gestational immunosuppression [14,15]. An important component of keeping pregnant women and women planning pregnancy is to determine the intensity of anti-measles immunity. In study [16], $21.5 \%$ (120 of 559) pregnant women were seronegative. In addition, it has been observed that with increasing gestational age, the number of seronegative results in infections such as measles and rubella increases [1].

Over the past few years in the modern literature, a number of publications have been published on the analysis of measles in pregnant women as a result of the recent epidemic rise of measles. Thus, according to the results of French researchers [17], during the epidemic rise of measles in Lyon, 13 cases of measles were registered in pregnant women, and every third patient had the disease complicated by pneumonia $(4-30.8 \%)$, but all of them gave birth to healthy newborns.

The most comprehensive analysis of clinical data on the course of measles in pregnant women is reported in the publications of Sudanese [18] and Namibian [19] researchers. These studies deserve special attention because they demonstrate a high incidence of measles complications and birth outcomes in pregnant measles patients, the vast majority of whom have not been vaccinated. In the study by A. A. Ali et al. [18] the course of measles and childbirth in 53 pregnant women, of whom only $19.7 \%$ had previously received vaccinations against this infection, are analyzed. The maternal mortality rate among pregnant women with measles reached $18.0 \%$ (11 out of 53), most often due to the development of pneumonia $(n=9)$, as well as encephalitis $(n=1)$, intracranial hemorrhage $(n=1)$. At the same time, in every fourth pregnant woman measles had a negative impact on pregnancy and led to abortions $(6-11.3 \%)$, premature births (4-7.5\%), stillbirths (3-5.7\%).

In the study of I. U. Ogbuanu et al. [19] the course of laboratory confirmed measles cases in 55 pregnant women, who were treated in 6 Namibian clinical institutions, was analyzed. Most pregnant women (67\%) who had measles did not have data on previous vaccinations. This study demonstrated a high incidence of complications in pregnant patients with measles, namely diarrhea (60\%), pneumonia (40\%), encephalitis (5\%). A comparison of the course of pregnancy in women with measles and pregnant women without measles made by researchers [19] showed that measles probably increases the risk of having a child with a low body weight, involuntary abortion, fetal death, and maternal mortality. The mortality rate among pregnant women with measles was $9.3 \%$, due to complications of both measles and pregnancy. Authors reported signs of congenital measles in $1(3.0 \%)$ newborn who was born prematurely at 32 weeks and died on the $15^{\text {th }}$ day due to lung damage. It is believed that measles virus has no teratogenic effect, but it does not rule out the possibility of damage to central nervous system and development of cardiovascular complications of inflammatory nature [10].

\section{Conclusions}

Acording to analysis of four observations we can determine that measles in pregnant women has both moderate and severe course, but development of complications from the respiratory system was recorded in the majority of patients (3 out of 4). In the presence of measles complications by the respiratory system, changes in the hemogram of pregnant patients were characterized by leukocytosis, expressed neutrophilosis with a shift of the leukocyte formula to the left, development of leukemoid reaction $(n=3)$, mononuclear reaction $(n=2)$, transient thrombocytopenia. The above clinical observation demonstrates the development of very severe complicated course of measles in an unvaccinated 25-year-old pregnant woman, which led to preterm birth at 30 weeks of gestation.

Prospects for further research. In our opinion, the promising direction of this research is the in-depth study of measles immunopathogenesis characteristics in pregnant women.

Conflicts of interest: authors have no conflict of interest to declare. Конфмікт інтересів: віАсутній.

Надійшла Ао редакції / Received: 04.02.2020

Після Аоопрацювання / Revised: 25.02.2020

Прийнято Ао Аруку / Accepted: 01.03.2020 
Information about authors:

Riabokon 0. V., MD, PhD, DSc, Professor, Head of the Department of Infectious Diseases, Zaporizhzhia State Medical University, Ukraine.

Izbytska N. H., MD, PhD, DSc, Associate Professor, Department of Obstetrics and Gynecology, Zaporizhzhia State Medical University, Ukraine.

Bilokobyla S. O., MD, Assistant of the Department of Infectious Diseases, Zaporizhzhia State Medical University, Ukraine. Onishchenko T. Ye., MD, PhD, Associate Professor of the Department of Infectious Diseases, Zaporizhzhia State Medical University, Ukraine.

Riabokon Yu. Yu., MD, PhD, DSc, Professor of the Department of Children Infectious Diseases, Zaporizhzhia State Medical University, Ukraine.

\section{Відомості про авторів:}

Рябоконь О. В., А-р меА. наук, професор, зав. каф. інфекційних хвороб, Запорізький Аержавний медичний університет, Україна. Ізбицька Н. Г., А-р меА.наук, Аоцент каф. акушерства та гінекології, Запорізький Аержавний медичний університет, Україна.

Білокобила С. О., асистент каф. інфекційних хвороб, Запорізький Аержавний медичний університет, Україна. Оніщенко Т. Є., канА. меА. наук, Аоцент каф. інфекційних хвороб, Запорізький Аержавний медичний університет, Україна. Рябоконь Ю. Ю., А-р меА. наук, професор каф. Аитячих інфекційних хвороб, Запорізький Аержавний меАичний університет, Україна.

\section{Сведения об авторах:}

Рябоконь Е. В., А-р меА. наук, профессор, зав. каф. инфекционных болезней, Запорожский государственный медицинский университет, Украина. Избицкая Н. Г., А-р меА. наук, Аоцент каф. акушерства и гинекологии, Запорожский государственный меАицинский университет, Украина.

Белокобыла С. А., ассистент каф. инфекционных болезней, Запорожский государственный медицинский университет, Украина.

Онищенко Т. Е., канА. меА. наук, Аоцент каф. инфекционных болезней, Запорожский государственный меАицинский университет, Украина.

Рябоконь Ю. Ю., А-р меА. наук, профессор каф. Аетских инфекционных болезней, Запорожский государственный медицинский университет, Украина.

\section{References}

[1] Zadorozhna, V. I., Marychev, I. L., Protsap, O. I. \& Bryzhata, S. I. (2019). Epidemichna sytuatsiia po zakhvoriuvanosti na kir v Ukraini u 2017-2018 r.r. [Epidemic situation of measles incidence in Ukraine in 2017-2018]. Infectious diseases of modern times: etiology, epidemiology, diagnosis, treatment, prevention, biological safety. Materials of Scientific and Practical Conference (pp. 76-79). Kyiv. [in Ukrainian].

[2] Kramarov, S. O., Yevtushenko, V. V., Kovalyukh, I. Yu., Kaminska, T. M., \& Golovach, O. V. (2018). Klinichna kartyna koru v ditei, hospitalizovanykh pid chas spalakhu 2017-2018 rr. [Clinical features of measles in children hospitalized during 2017-2018 outbreak]. Aktualna infektolohiia - Actual infectology, 6(5), 55-60. [in Ukrainian]. https://doi. org/10.22141/2312-413x.6.5.2018.146773

[3] Rota, P. A., Brown, K., Mankertz, A., Santibanez, S., Shulga, S., Muller, C. P., ... Featherstone, D. (2011). Global distribution of measles genotypes and measles molecular epidemiology. Journal of Infectious Diseases, 204(Suppl. 1). https://doi.org/10.1093/infdis/jir118

[4] Werber, D., Hoffmann, A., Santibanez, S., Mankertz, A., \& Sagebiel, D. (2017). Large measles outbreak introduced by asylum seekers and spread among the insufficiently vaccinated resident population Berlin, October 2014 to August 2015. Eurosurveillance, 22(34), 6-13, Article 30599. https://doi.org/10.2807/1560-7917.es.2017.22.34.30599

[5] Grammens, T., Schirvel, C., Leenen, S., Shodu, N., Hutse, V., da Costa, E. M., \& Sabbe, M. (2017). Ongoing measles outbreak in Wallonia, Belgium, December 2016 to March 2017: characteristics and challenges. Eurosurveillance, 22(17), 5-9, Article 30524. https:// doi.org/10.2807/1560-7917.es.2017.22.17.30524

[6] Pavlenova, O. Yu., Ushenina, L. A., Ryabokon, E. V., Mashko, O. P. Furik, E. A., Ushenina, N. S., Savelyev, V. G., Onishchenko, T. E., \& Firyulina, O. M. (2013). Osoblyvosti zmin pokaznykiv funktsionalnoho stanu vehetatyvnoi nervovoi systemy u khvorykh na kir [Peculiarities of changes of autonomic nervous system functional state in patients with measles]. Zaporozhye Medical Journal, (2), 39-41. [in Ukrainian].

[7] Moyseyeva, A. V., Zadorozhna, V. I., Demchyshyna, I. V., \& Novyk, L. V. (2010). Monitorynh populiatsiinoho imunitetu proty koru naselennia Ukrainy [Monitoring of population's immunity is against measles of population in Ukraine]. Infektsiini khvoroby, (3), 5-13. [in Ukrainian]. https://doi.org/10.11603/1681-2727.2010.3.671

[8] Usachova, O. V., Silina, Ye. A., Pakholchuk, T. N., Konakova, O. V., Dralova, O. A., Puhir, V. P., Firyulina, O. M., \& Zelenukhina, E. V. (2019). Kir - kerovana infektsiia! Deiaki epidemiolohichni paradyhmy koru u Zaporizkii oblasti [Measles - controlled infection! Some epidemiological paradigm of measles in Zaporizhzhia region]. Sovremennaya Pediatriya, (1), 13-18. [in Ukrainian]. https://doi.org/10.15574/SP.2019.97.13

[9] Timchenko, V. N., Kaplina, T. A., Bulina, O. V., Leonicheva, O. A., Khakizimana, Zh. K., \& Timofeeva, E. V. (2017). Aktual'nye problemy korevoi infektsii [Actual problems of measles infection]. Pediatriya, 8(3), 120-129. [in Russian]. https://doi.org/10.17816/PED83120-129

[10] Demenina, N. K., \& Ishchenko, H. I. (2018). Vplyv infektsii koru na vahitnist ta metody profilaktyky (ohliad literatury) [Influence of measles on pregnancy and prevention methods (a literature review)]. Perinatologiya i pediatriya, (1), 80-83. [in Ukrainian]. https://doi.org/10.15574/ PP.2018.73.83

[11] Trykhlib, V. I., Shchur, A. B., Hrushkevych, V. V., Hryshyn, O. S. Pavlovska, M. O., Musiienko, T. I., Muzyka, H. A., Ralets, N. V., Dudar, D. M., \& Kozachenko, L. V. (2018). Osoblyvosti klinichnykh proiaviv ta perebihu koru [Features of clinical manifestations and course of measles]. Aktualna infektolohiia, 6(3), 36-47. [in Ukrainian]. https:// doi.org/10.22141/2312-413x.6.3.2018.136647

[12] Yasunaga, H., Shi, Y. J., Takeuchi, M., Horiguchi, H., Hashimoto, H. Matsuda, S., \& Ohe, K. (2010). Measles-related Hospitalizations and Complications in Japan, 2007-2008. Internal Medicine, 49(18), 19651970. https://doi.org/10.2169/internalmedicine.49.3843

[13] World Health Organization. (2012). Surveillance Guidelines for Measles, Rubella and Congenital Rubella Syndrome in the WHO European Region. Geneva: WHO.

[14] Hnatyuk V. V., \& Pokrovska T. V. (2015). Uskladnennia koru v ditei doroslykh [Complications of measles in children and adults]. Bukovynskyi medychnyi visnyk, 19(2), 48-51. [in Ukrainian].

[15] Shostakovych-Koretsraya, L. R., Mavrutenkov, V. V., Cherhinets, A. V. Budayeva, I. V., Yakunina, O. M., \& Chykarenko, Z. A. (2013). Kir (lektsiia, prodovzhennia) [Measles (lecture, continued)]. Medychni perspektyvy, 18(3), 4-15. [in Ukrainian].

[16] Nozdracheva, A. V., Semenenko, T. A., Mardanly, S. G., \& Rotanov, S. V. (2017). Otsenka napryazhennosti gumoral'nogo immuniteta k kori i krasnukhe u beremennykh zhenshchin v Moskve [Evaluation of intensity of humoral immunity to measles and rubella in pregnant women in Moscow]. Zhurnal mikrobiologii, (3), 91-98. [in Russian].

[17] Casalegno, J. S., Huissoud, C., Rudigoz, R., Massardier, J., Gaucherand, P., \& Mekki, Y. (2014). Measles in pregnancy in Lyon France, 2011. International Journal of Gynecology \& Obstetrics, 126(3), 248-251. https://doi.org/10.1016/i.ijgo.2014.03.021

[18] Ali, A. A., Abdelhameed, O., \& Abdallah, T. M. (2014). Case-fatality rate associated with measles during pregnancy in Kassala, eastern Sudan. International Journal of Gynecology \& Obstetrics, 124(3), 261-262. https://doi.org/10.1016/i.ijgo.2013.09.015

[19] Ogbuanu, I. U., Zeko, S., Chu, S. Y., Muroua, C., Gerber, S. De Wee, R., Kretsinger, K., Wannemuehler, K., Gerndt, K., Allies, M. Sandhu, H. S., \& Goodson, J. L. (2014). Maternal, Fetal, and Neonatal Outcomes Associated With Measles During Pregnancy: Namibia 2009-2010. Clinical Infectious Diseases, 58(8), 1086-1092. https:// doi.org/10.1093/cid/ciu037 